\title{
Desain Penyeimbangan Sel Baterai Lithium-Ion dengan Teknik Cell-to-Cell Charging Mode pada Battery Management System (BMS)
}

\author{
Khaeruddin $^{1}$, Wijono ${ }^{2}$, Rini Nur Hasanah ${ }^{3}$ \\ Jurusan Teknik Elektro, Universitas Brawijaya Malang1 \\ Jurusan Teknik Elektro, Universitas Brawijaya Malang² \\ Jurusan Teknik Elektro, Universitas Brawijaya Malang ${ }^{3}$ \\ *lamone41@gmail.com¹,wijono@ub.ac.id², rini.hasanah@ub.ac.id ${ }^{3}$
}

\begin{abstract}
This paper discusses the balance between lithium-ion battery cells in the BMS (Battery Management System) of an electric car. The unbalanced condition during the battery charging process is caused by one of the batteries that are fully charged while part of it is still half or even only half-full. This condition can cause the battery to heat up quickly, and pass the SOA (safety of area) condition, causing a fire in the battery. In this study, the cell-to-cell technique is proposed to balance the charge to each battery cell to approximate the same condition. The simulation results show that the use of cell-to-cell balancing technique can balance the battery charge. The charging process for battery1, battery2, battery 3 has different voltages $4.15 \mathrm{~V}, 4.20 \mathrm{~V}$, and $4.25 \mathrm{~V}$. The balancing occurs at the beginning of the $6000 \mathrm{~s}$, while the overall balancing of the battery occurs at 10000s, which is both $4.15 \mathrm{~V}$ and the current has decreased significantly..
\end{abstract}

Keywords: Balancing, Cell, Battery, Lithium-ion, Cell-to-Cell, BMS.

\section{INTISARI}

Makalah ini membahas tentang penyeimbangan arus charging baterai lithium-ion pada BMS (Battery Management System) mobil listrik. Kondisi tidak seimbang pada saat proses pengisian baterai disebabkan karena salah satu baterai yang sudah terisi penuh sedangkan sebagiannya masih separuh atau bahkan hanya seperampat saja yang terisi. Kondisi ini dapat menyebabkan baterai cepat panas, serta melewati kondisi SOA (Safety of Area) sehingga menyebabkan kebakaran pada baterai. Pada penelitian ini, teknik cell-to-cell diusulkan untuk menyeimbangkan arus pengisian ke masing-masing sel baterai agar mendekati kondisi sama rata. Hasil simulasi menunjukan bahwa penggunaan teknik balancing cell-to-cell dapat menyeimbangkan sel baterai selama masa pengisian. Proses charging untuk baterai1, baterai2, baterai3 mempunyai tegangan yang berbeda yaitu 4,15V, 4,20V, dan 4,25V . Awal terjadi penyeimbangan pada waktu 6000s, sedangkan mulai terjadi penyeimbangan secara keseluruhan baterai terjadi di waktu 10000 s yaitu sama-sama $4,15 \mathrm{~V}$ dan arus mengalami penurunan secara signifikan.

Kata kunci: Penyeimbangan, Sel, Baterai, Lithium-ion, Cell-to-Cell, BMS.

\section{PENDAHULUAN}

Penelitian ini membahas tentang desain penyeimbangan sel baterai lithium-ion dengan teknik cell-to-cell pada BMS (Baterai Management System). Kondisi tidak seimbang pada baterai disebabkan karena adanya perbedaan tegangan antara sel dalam satu battery-pack[1]. Ketidakseimbangan sel (cell imbalanace) pada baterai dapat mempengaruhi proses charging/discharging baterai lithium-ion, yang pertama SOC (State of Charge) imbalance disebabkan oleh proses charging pada beberapa sel yang mempunyai level $S O C$ yang berbeda, kedua perbedaan kapasitas total baterai, ketiga perbedaan impedansi[2][13]. Secara umum teknik penyeimbangan sel baterai ada dua yaitu : cell-to-cell dan cell-to-bateray, teknik cell-to-cell digunakan untuk penyeimbangan skala kecil dan menengah, sedangkan untuk tenik cell-to-battery digunakan untuk penyeimbangan skala yang lebih kompleks[3]. Pada penelitian ini menggunakan teknik penyeimbangan cell-to-cell. 
Jurnal ECOTIPE, Vol. 8, No.1, April 2021, Hal. 9-15

p-ISSN 2355-5068, e-ISSN 2622-4852

Akreditasi Kemenristekdikti (SINTA 4), SK. No.10/E/KPT/2019

DOI: 10.33019/jurnalecotipe.v8i1.2137

Kondisi sel baterai yang tidak seimbang dapat menyebabkan thermal runaway, cell degradation, incomplete cahrging, dan incomplete discharging. Solusi yang diusulkan menggunakan teknik penyeimbangan cell-to-cell untuk membuat sel baterai dalam kondisi seimbang[4][14].

\section{LANDASAN TEORI}

\section{A. Cell Balancing}

Kondisi sel baterai yang tidak seimbang dapat menyebabkan kerusakan lebih dini pada sel tersebut. Ketidakseimbangan dapat menciptakan ruangan kosong dalam sel-sel battery-pack, contoh pada Gambar 1 tiap-tiap sel memiliki SOC yang berbeda. Pada gambar (a) sebelum dilakukan proses penyeimbangan, banyak ruang kosong yang belum sepenuhnya terisi. Pada gambar (b) setelah proses penyeimbangan, sel 1 dijadikan acuan saat proses berlangsung, setelah proses tersebut selesai tidak banyak lagi ruang kosong yang ada atau bisa dikatakan kondisi SOC battery-pack sudah hampir sama[1].

Teknik balancing ada dua, passive balancing dan active balancing. passive balancing bekerja dengan cara mengambil muatan dari sel yang mempunyai $S O C$ paling banyak dan ditransfer ke sel yang memiliki SOC paling sedikit. Cara ini menimbulkan efek panas pada baterai, sifat dari teknik ini energi terbuang dalam bentuk panas karena hanya sebagian sel yang terisi penuh. Active balancing bekerja dengan cara mengambil muatan dari sel yang muatannya paling banyak dan ditransfer ke sel yang muatan energinya paling sedikit, sehingga muatan energi pada sel yang ada didalam battery pack persis sama sifat dari teknik ini energi teralirkan antara sel, sehingga kondisi antar sel seimbang dan tidak menghasilkan panas[5][11]

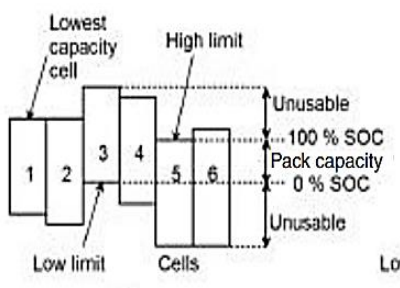

(a)

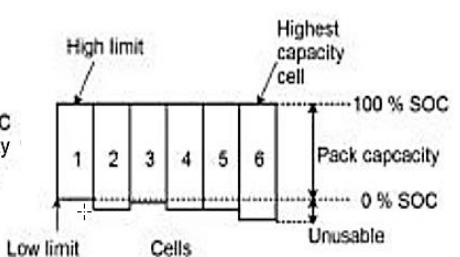

(b)
Gambar 1. Proses penyeimbangan baterai: (a) baterai tak seimbang, (b) baterai seimbang

\section{B. Teknik Penyeimbang Cell-to-Cell}

Metode ini menggunakan satu induktor yang berfungsi untuk menjaga keseimbangan battery-pack termasuk semua sel[6]. Rangkaian teknik penyeimbangan cell-to-cell dengan menggunakan satu induktor dapat dilihat pada Gambar 2.

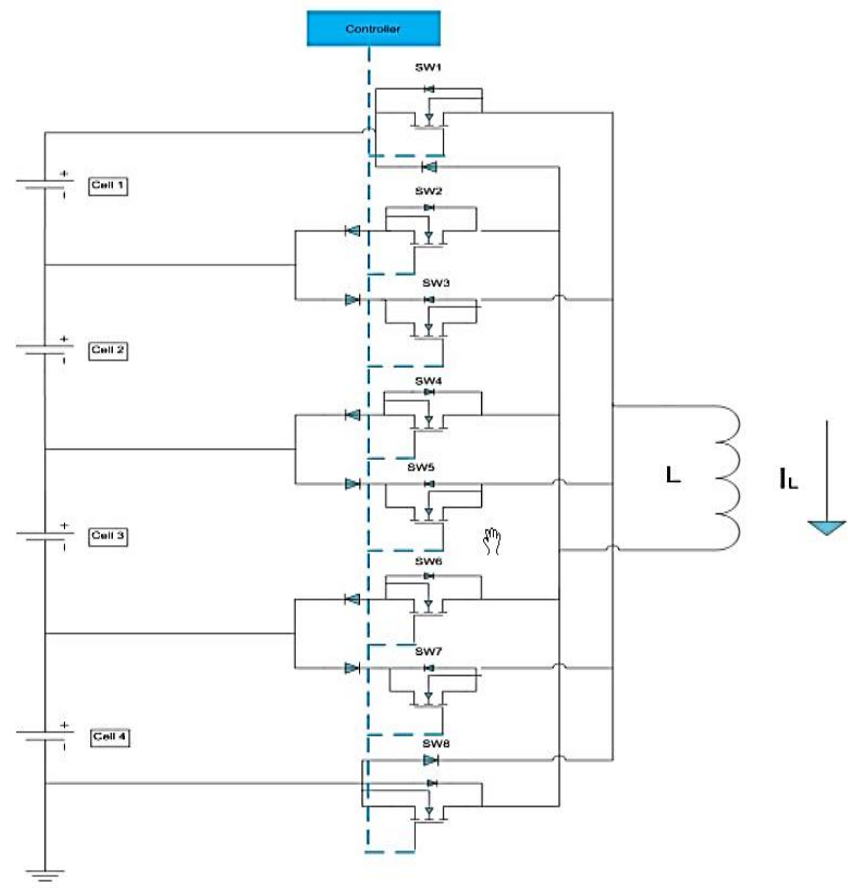

Gambar 2. Rangkaian active cell balancing single inductor

Metode ini dapat melakukan proses penyeimbangan di seluruh sel yang ada pada batterypack, siklus kerja switching penyeimbangan adalah $50 \%$. Kontroller memilih sel yang memiliki SOC paling tinggi dan $S O C$ paling rendah, kemudian energi dialirkan dari yang $S O C$ paling tinggi ke $S O C$ paling rendah[7]. Cara kerja rangkaian ini terdiri dari dua tahap, pertama dari sel yang memiliki SOC paling tinggi ke induktansi dalam setengah siklus, kedua dari induktor ke sel yang memiliki SOC paling rendah untuk setengah siklus berikutnya. energi ditransfer dari induktor ke sel SOC lebih rendah[8][9].

\section{Desain model baterai Lithium-ion}

Blok Equivalent Circuit Battery mengimplementasikan sirkuit baterai Resistor-Capasitor $(R C)$ yang dapat diparameterkan menggunakan Equivalent Circuit 
Jurnal ECOTIPE, Vol. 8, No.1, April 2021, Hal. 9-15

p-ISSN 2355-5068, e-ISSN 2622-4852

Akreditasi Kemenristekdikti (SINTA 4), SK. No.10/E/KPT/2019

DOI: 10.33019/jurnalecotipe.v8i1.2137

Modeling (ECM). Untuk mensimulasikan State-OfCharge (SOC) dan tegangan terminal blok menggunakan arus beban dan suhu inti internal. Blok Equivalent Circuit Battery menghitung tegangan dari baterai gabungan menggunakan tabel lookups parameter. [10]

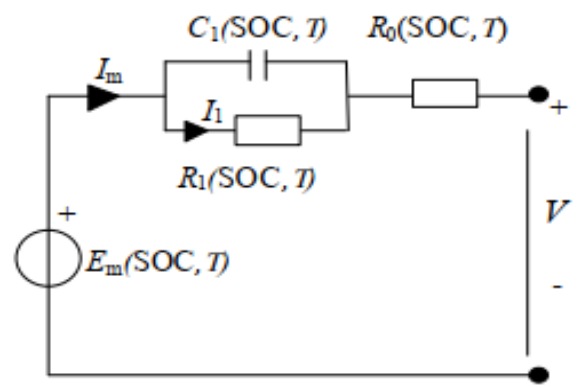

Gambar 3. One time constant model (OTC) Equivalent Circuit Battery

Kemudian melakukan perhitungan state-ofcharge SOC adalah sebagai berkut:

$S O C=1-Q e / C Q$.

Dimana CQ adalah kapasitas dari cell pada arus discharge, akibatnya apapun definisi SOC harus mempertimbangkan kondisi di bawah dimana sel dilepaskan dan mengacu pada arus dan suhu keluaran tertentu di mana SOC telah dievaluasi. [10] Fungsi tiap elemen yang ada pada Gambar 3 one time constant model (OTC) Equivalent Circuit Battery adalah fungsi SoC dan suhu, berikut ini adalah uraiannya [10]

$$
\begin{aligned}
& R 0=R 0(S O C, T) \ldots \\
& R 1=R 1(S O C, T) \ldots \\
& C 1=C 1(S O C, T) \ldots \\
& E m=E m(S O C, T)
\end{aligned}
$$

Pemodelan onetime constant model (OTC) Equivalent Circuit Battery didalam simscape matlab dapat dilihat pada Gambar 4.[10][12]

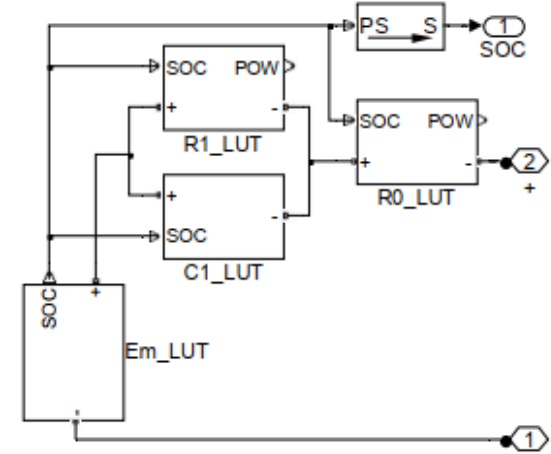

Gambar 4. Model Simscape Equivalent Circuit Battery

\section{METODE PENELITIAN}

Teknik penyeimbangan cell-to-cell diusulkan untuk menyeimbangkan antar sel baterai. Aplikasi Matlab-R2018b digunakan untuk mendesain dan merancang Battery Management System (BMS).

\section{A. Perancangan Cell Baterai}

Rangkaian dasar ekivalen baterai dirancang dalam simulasi SimScape MATLAB Simulink, dimana untuk satu cell baterai diwakili oleh dua buah Resistor, satu buah kapasitor dan satu sumber tegangan. Pada perancangan model baterai ini memanfaatkan SimSpace Component yang bisa di customize berdasarkan kebutuhan, contohnya disini adalah komponen resistor, kapasitor, dan voltage source. Untuk masing-masing komponen lain seperti kapacitor dan voltage source juga di inputkan listing code pada SimScape Component yang sudah di create. Setelah semua komponent dicreate dan selesai langsung semua kompoen itu dirangkai menjadi sebuah Cell Baterai.

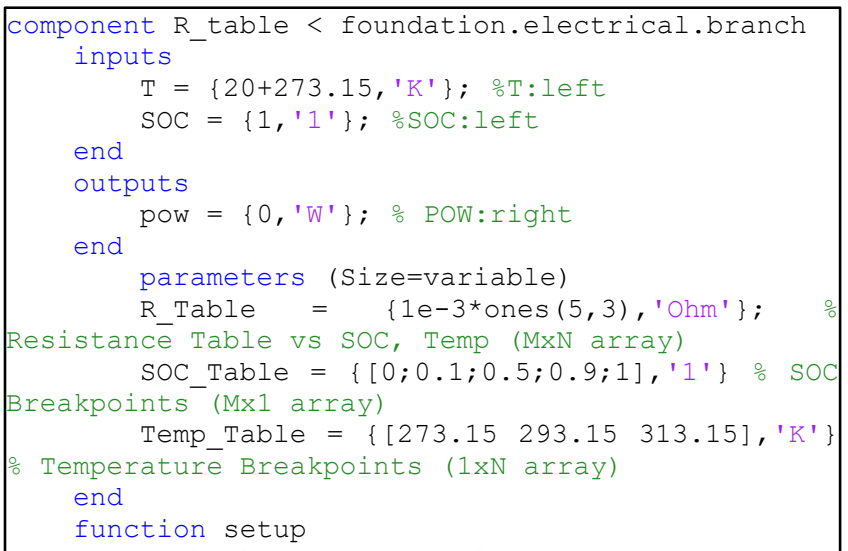


Jurnal ECOTIPE, Vol. 8, No.1, April 2021, Hal. 9-15

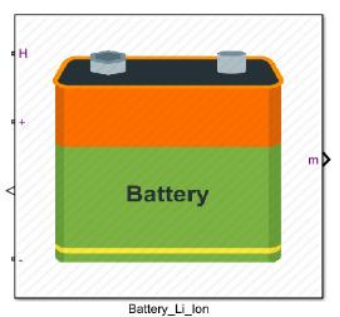

Gambar 5. Sel Baterai di MATLAB

\section{B. Perancangan Cell Baterai}

Teknik penyeimbangan yang digunakan dalam penelitian ini adalah teknik cell-to-cell salah satu model rangkain yang menggunakan prinsip kerja ini adalah single modle inductor.

Tabel 1. Teknik penyeimbangan cell-to-cell pada rangkaian single inductor model

\begin{tabular}{|c|c|c|c|c|c|c|}
\hline $\begin{array}{l}\text { CELL } \\
\text { H-SoC }\end{array}$ & $\begin{array}{c}\text { CELL } \\
1\end{array}$ & $\begin{array}{c}\text { CELL } \\
1\end{array}$ & $\begin{array}{c}\text { CELL } \\
2\end{array}$ & $\begin{array}{c}\text { CELLL } \\
2\end{array}$ & $\begin{array}{c}\text { CELLL } \\
3\end{array}$ & $\begin{array}{c}\text { CELI } \\
3\end{array}$ \\
\hline $\begin{array}{l}\text { CELL } \\
\text { L-SoC }\end{array}$ & $\begin{array}{c}\text { CELIL } \\
2\end{array}$ & $\begin{array}{c}\text { CELL } \\
3\end{array}$ & $\begin{array}{c}\text { CELL } \\
1\end{array}$ & $\begin{array}{c}\text { CELLL } \\
3\end{array}$ & $\begin{array}{c}\text { CELL } \\
1\end{array}$ & $\begin{array}{c}\text { CELI } \\
2\end{array}$ \\
\hline $\begin{array}{c}\mathrm{T}_{\mathrm{ON}=} \alpha \mathrm{T} \\
\mathrm{c}\end{array}$ & $\mathrm{Q} 4, \mathrm{Q} 9$ & $\begin{array}{l}\text { Q4, } \\
\text { Q9 }\end{array}$ & Q5,Q8 & Q5,Q8 & Q1,Q7 & $\mathrm{Q1}^{2} \mathrm{Q}$ \\
\hline $\begin{array}{l}\mathrm{T}_{\mathrm{OFF}}=\mathrm{T} \\
\mathrm{C}-\mathrm{T}_{\mathrm{ON}}\end{array}$ & $\mathrm{Q} 4, \mathrm{Q} 7$ & Q5,Q6 & Q3,Q8 & Q5,Q6 & Q3,Q8 & $\mathrm{Q} 4, \mathrm{Q} 7$ \\
\hline
\end{tabular}

Proses teknik penyeimbangn cell-to-cell pada rangkaian single modle inductor dapat dilihat pada tabel 1. Adapun proses switching antara charging dan discharging antar sel, Jika CELL1 dalam kondisi muatan terisi penuh dan CELL2 dalam kondisi muatan tidak terisi penuh, maka muatan yang tersimpan dalam CELL1 akan ditransfer ke CELL2 yang masih memiliki ruang kosong untuk menampung muatan.

Pada proses transfer muatan memiliki dua tahapan yaitu, pertama muatan akan ditransfer terlebih dahulu ke induktor, induktor disini berfungsi untuk menyimpan sementara muatan yang akan di transfer nantinya ke CELL2 dengan mengaktifkan Q4 dan Q9, kedua muatan yang tersimpan di induktor akan ditransfer ke CELL2 yang masih memiliki ruang kosong penyimpanan dengan mengaktifkan Q4 dan Q7.

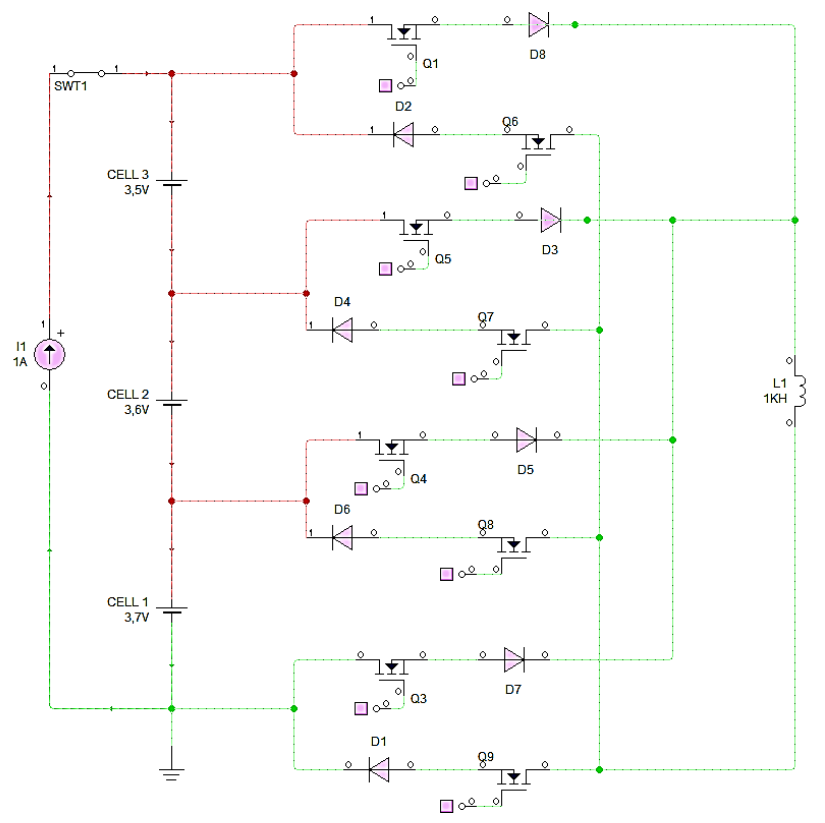

Gambar 6. Rangkaian single inductor model

\section{HASIL PENELITIAN DAN PEMBAHASAN}

Hasil simulasi dari penyeimbangan sel baterai lithium-ion dengan teknik cell-to-cell charging mode pada Battery Management System (BMS) secara keseluruhan berikut.

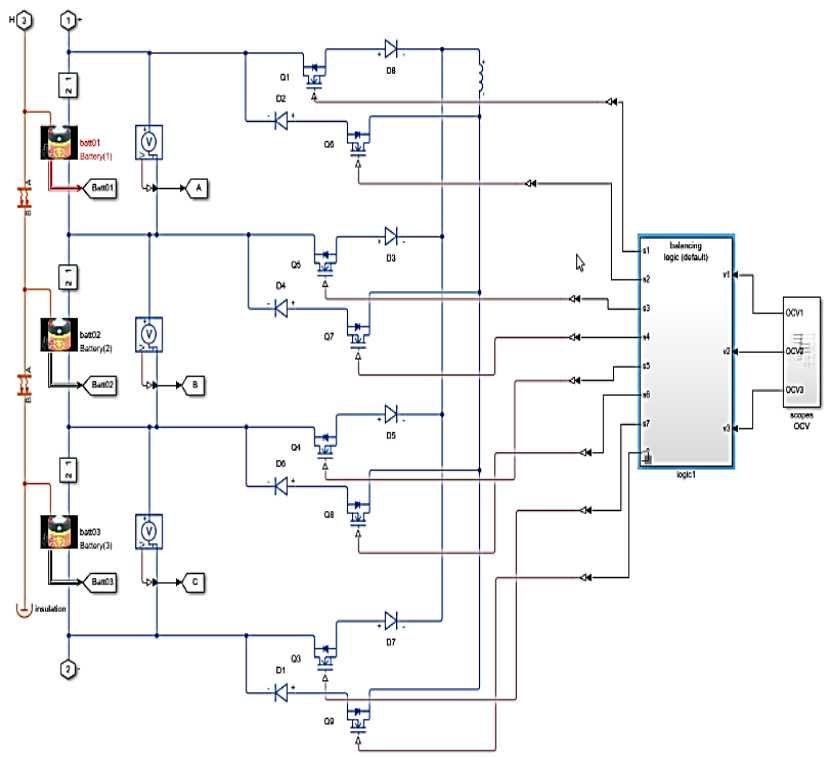

Gambar 7. Rangkaian single inductor model di MATLAB 
Jurnal ECOTIPE, Vol. 8, No.1, April 2021, Hal. 9-15

p-ISSN 2355-5068, e-ISSN 2622-4852

Akreditasi Kemenristekdikti (SINTA 4), SK. No.10/E/KPT/2019

DOI: 10.33019/jurnalecotipe.v8i1.2137

Pada Gambar 8 merupakan proses sel balancing antara ketiga sel, untuk warna merah sel SOC 1, warna biru sel SOC 2, warna kuning sel SOC 3.

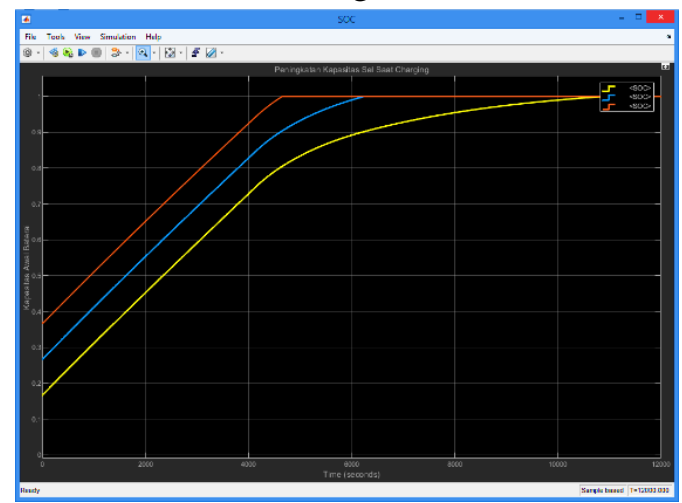

Gambar 8. Sel Balancing SOC saat mode charging pada sel baterai

Proses charging dimulai dengan nilai SOC yang berbeda, terlihat bahwa SOC dari setiap sel terkonvergensi ke nilai yang terus meningkat selama pengisian baterai seperti yang ditunjukkan pada Gambar 8, jika diperbesar terlihat pada Gambar 9.

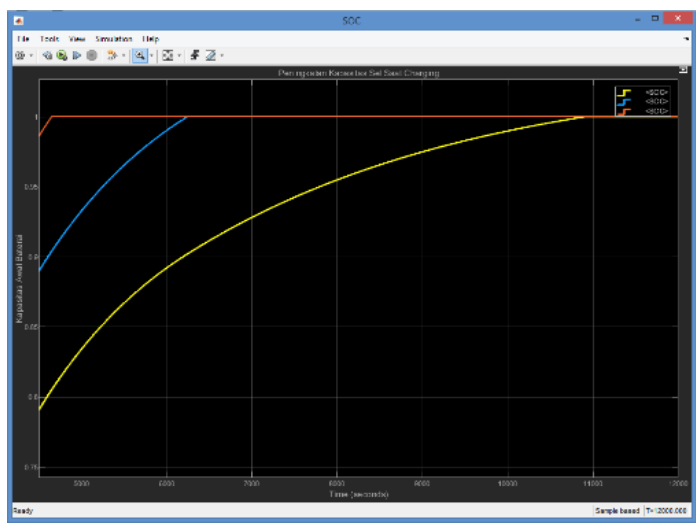

Gambar 9. Cell Balancing SOC saat mode charging pada sel baterai diperbesar

Seperti pada karakteristik lithium-ion LIR 18650, jika tegangan semakin meningkat pada saat proses charging maka arus akan berada di posisi sebaliknya yaitu akan menurun seperti terlihat pada Gambar 9. Pada Gambar 8 menunjukan peningkatan kapasitas baterai1, baterai2 dan baterai3 saat terjadi proses charging, untuk baterai 2 dan baterai3 yang paling cepat mengalami peningkatan kapasitas.
Ini terjadi karena kondisi kapasitas awal kedua baterai ini lebih besar jika dibandingkan dengan baterai1. Mulai terjadi penyeimbangan antara baterai dan baterai dua pada waktu 6000s sedangkan terjadi penyeimbangan kapasitas pada ketiga baterai di waktu 10000s.

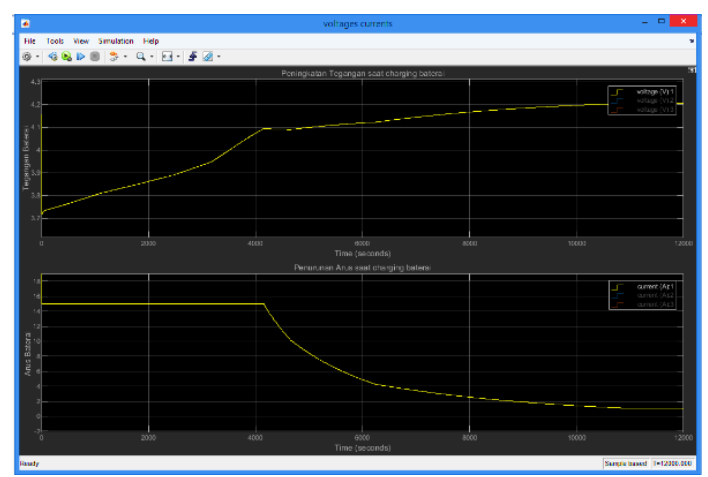

Gambar 10. Proses charging tegangan pada baterai 1 meningkat arus menurun

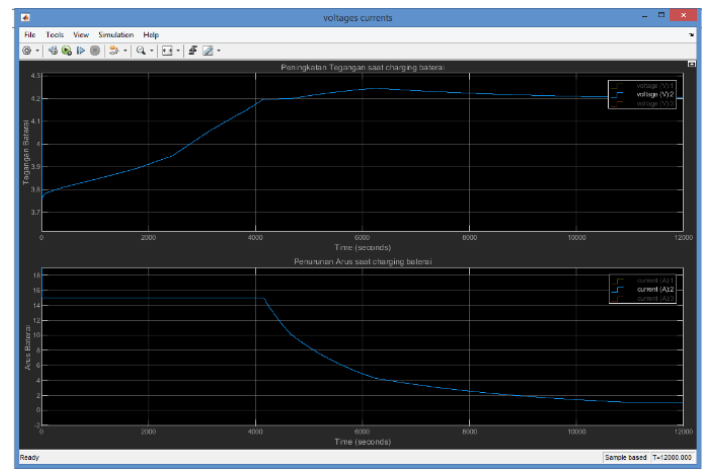

Gambar 11. Proses charging tegangan pada baterai 2 meningkat arus menurun

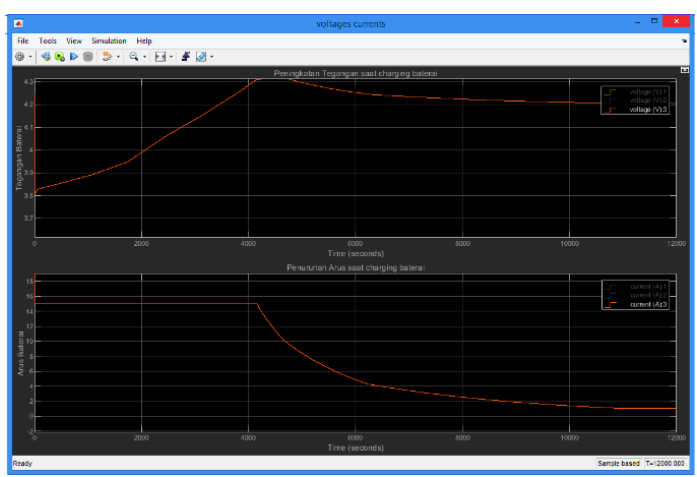

Gambar 12. Proses charging tegangan pada baterai 3 mingkat arus menurun 
Jurnal ECOTIPE, Vol. 8, No.1, April 2021, Hal. 9-15

p-ISSN 2355-5068, e-ISSN 2622-4852

Akreditasi Kemenristekdikti (SINTA 4), SK. No.10/E/KPT/2019

DOI: 10.33019/jurnalecotipe.v8i1.2137

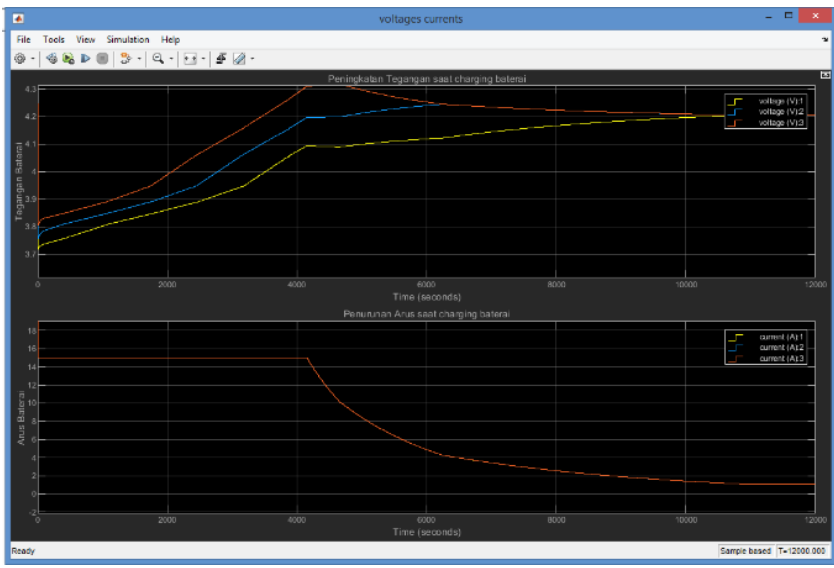

Gambar 13. Proses charging tegangan pada semua baterai

Pada Gambar 10 s/d Gambar 13 menunjukan tegangan dan arus yang terisi ke baterai1, baterai2, dan baterai3. Proses charging untuk baterai1, baterai2, baterai3 mempunyai tegangan yang berbeda yaitu $4,15 \mathrm{~V}, 4,20 \mathrm{~V}$, dan $4,25 \mathrm{~V}$. Untuk baterai1 dan baterai2 mulai terjadi penyeimbangan pada waktu 6000s, sedangkan mulai terjadi penyeimbangan secara keseluruhan baik antara baterai1, baterai2, dan baterai3 terjadi di waktu 10000 s yaitu sama-sama $4,15 \mathrm{~V}$ dan arus mengalami penurunan secara signifikan.

\section{KESIMPULAN}

Makalah ini mengusulkan rangkaian penyeimbang baterai otomatis dengan pengontrol sakelar berbasis SOC yang menyeimbangkan SOC dengan teknik cellto-cell. Pada penelitian ini terlihat bahwa setelah sel paket baterai seimbang maka semua sel memiliki SOC yang sama selama pengisian. Proses charging untuk baterai1, baterai2, baterai3 mempunyai tegangan yang berbeda yaitu $4,15 \mathrm{~V}, 4,20 \mathrm{~V}$, dan $4,25 \mathrm{~V}$. Awal terjadi penyeimbangan pada waktu 6000s, sedangkan mulai terjadi penyeimbangan secara keseluruhan baterai terjadi di waktu 10000 s yaitu sama-sama $4,15 \mathrm{~V}$ dan arus mengalami penurunan secara signifikan.

\section{REFERENSI}

[1] Andrea, D. (2010). Battery Management Systems for Large Lithium-Ion Battery Packs. Artech House

[2] Barsukov, Y. (2010) Battery Cell Balancing: What to Balance and How, Texas Instrument Inc.
[3] Plett, G. L. (2015) Battery Management Systems: Volume I Battery Modeling, Artech House

[4] S. Park, Tae-Sung Kim, Jin-Sik Park, Gun-Woo Moon and Myung-Joong Yoon, "A new battery equalizer based on buck-boost topology," 2007 7th Internatonal Conference on Power Electronics, Daegu, 2007, pp. 962-965, doi: 10.1109/ICPE.2007.4692526.

[5] Reynaud, J.F., Carrejo, C.E, Gantet, O., Aloisi, P., Estibals, B., \& Alonso, C. (2010). Active Balancing circuit for advanced Lithium-ion batteries used in photovoltaic application. Internasional Conference on Renewable Energies and power Quality, ICREPQ'11, Las palmas de gran canaria, Spanyol, 13-15 April 2010, doi:10.24084/REPQJ09.682

[6] Najmabdi A, (2013), Evaluation of Active Balancing Algorithms and an Improved Method for a Deployed Active Battery Balancer as Well as Physical Implementation. Master Thesis, Published, Hamilton, Ontario, Canada: McMaster University.

[7] Soeprapto, Hasanah, R.N., \& Taufik, (2019). Battery Managment system on electric bike using lithium-ion 18650, Internasional Journal of Power Electronics and Driver System, IJPEDS. X, (3) : 1529 - 1537, doi:/10.11591/ijpeds.v10.i3.pp15291537

[8] M. Daowd, N. Omar, P. Van Den Bossche and J. Van Mierlo, "Passive and active battery balancing comparison based on MATLAB simulation," 2011 IEEE Vehicle Power and Propulsion Conference, Chicago, IL, 2011, pp. 17, doi: 10.1109/VPPC.2011.6043010.

[9] J. Cao, N. Schofield and A. Emadi, "Battery balancing methods: A comprehensive review," 2008 IEEE Vehicle Power and Propulsion Conference, Harbin, 2008, pp. 1-6, doi: 10.1109/VPPC.2008.4677669.

[10] T. Huria, M. Ceraolo, J. Gazzarri and R. Jackey, "High fidelity electrical model with thermal dependence for characterization and simulation of highpower lithium battery cells," 2012 IEEE International Electric Vehicle Conference, Greenville, SC, 2012, pp. 1-8, doi: 10.1109/IEVC.2012.6183271.

[11] Hu, Rui., (2011), Battery Management System For Electric Vehicle Applications. Master Thesis, 
Jurnal ECOTIPE, Vol. 8, No.1, April 2021, Hal. 9-15

p-ISSN 2355-5068, e-ISSN 2622-4852

Akreditasi Kemenristekdikti (SINTA 4), SK. No.10/E/KPT/2019

DOI: 10.33019/jurnalecotipe.v8i1.2137

Published, Windsor, Ontario, Canada: University of Windsor.

[12] S. Park, K. Park, H. Kim, G. Moon and M. Youn, "Single-Magnetic Cell-to-Cell Charge

Equalization Converter With Reduced Number of Transformer Windings," in IEEE Transactions on Power Electronics, vol. 27, no. 6, pp. 2900-2911, June 2012, doi: 10.1109/TPEL.2011.2178040.

[13] Nellis, K.L., (2015), Cell-balancing and State of Charge Algorithms, Analysis of LFEV's project design, Easton, Pennsylvania, doi:36101842

[14] Uitz, M., Sternad, M., Breuer, S., Taubert, C., Traubnig, T., Hanzu, I., \& Wilkening, M., (2017), Aging of Tesla's 18650 Lithium-Ion Cells: Correlating Solid-Electrolyte-Interphase Evolution with Fading in Capacity and Power. Journal of The ELectrochemical Society, ECS, IV, (164): A3503-A3510, (2017), doi:10.1149/2.0171714jes 